Artikel Penelitian

\title{
Gambaran Tingkat Kebisingan Akibat Suara Kendaraan Bermotor di Beberapa Sekolah Berlokasi di Sekitar Jalan Raya kota Padang
}

\author{
Galan Eko Saputro ${ }^{a}$, Meifal Rusli ${ }^{a}$ \\ ${ }^{a}$ Jurusan Teknik Mesin, Fakultas Teknik, Universitas Andalas, Kampus Limau Manis, Padang 25165 - Indonesia
}

INFORMASI ARTIKEL

Sejarah Artikel:

Diterima Redaksi: 08 Februari 2019

Revisi Akhir: 22 Maret 2019

Diterbitkan Online: 29 April 2019

KATA KUNCI

Kebisingan

Tingkat tekanan suara

Ambang batas kebisingan

Jalan raya

sekolah

\section{KORESPONDENSI}

E-mail: meifal@eng.unand.acid

\section{A B S T R A C T}

Concern about noise pollution has been increasing in worldwide nowadays, especially in industrial and urban areas. Children could be particularly vulnerable to the effects of noise because of its potential to interfere with learning at a critical development stage. Most of the learning occurs at school and thus noise exposure at school gives significant influence on learning performance. According to World Health Organization (WHO), traffic is one of the main sources of environmental noise exposure in urban communities, including school. This paper will review the noise level in some schools located near the main traffic road around Andalas and Simpang Haru area of Padang City, West Sumatera Province. Sound levels are measured at four points, i.e. at the main road in front of school, school gate, the nearest and farthest class room from the main road. The measurements are conducted from $7.00 \mathrm{am}$ in the morning to $04.00 \mathrm{pm}$ in the afternoon. It is found that almost in all positions in the schools are exposure by noise above the threshold limit value reversed by WHO and Indonesian Government $55 \mathrm{dBA}$. In the morning when the peak time of the traffic session, the noise levels from the class to the gate are around $70 \mathrm{dBA}$ to $85 \mathrm{dBA}$, and its decrease to $50 \mathrm{dBA}$ and $75 \mathrm{dBA}$ in the afternoon. Some noise is possibly generated not only by traffic noise, but the noise graphics are seemed to be related to the traffic noise in the road.

\section{PENDAHULUAN}

Kebisingan adalah tingkat suara yang tidak dikehendaki dan dapat mengganggu kenyamanan dan kesehatan lingkungan yang dinyatakan dalam satuan desibel (dB) [1]. Kebisingan juga dapat didefinisikan sebagai bunyi yang tidak dikehendaki karena tidak sesuai dengan konteks ruang dan waktu sehingga dapat menimbulkan gangguan terhadap kenyamanan dan kesehatan manusia [2].

Kebisingan mempengaruhi kesehatan manusia baik secara fisik maupun psikologis. Pada tahun 1993, WHO mengakui efek kesehatan penduduk yang berasal dari kebisingan, antara lain gangguan pola tidur, kardiovaskuler, sistem pernafasan, psikologis, fisiologis, dan pendengaran. Kebisingan juga berpengaruh negatif dalam komunikasi, produktivitas dan perilaku sosial [3]. Disamping itu kebisingan juga akan mengakibatkan gangguan kemampuan berbicara dan gangguan komunikasi, gangguan untuk mendapatkan informasi, dan gangguan berkonsentrasi [1].

Kebisingan yang terjadi di sekolah secara terus menerus memberikan pengaruh yang negatif yang kronis terhadap kemampuan belajar dan tingkat kecerdasan anak, antara lain kemampuan konsentrasi, penurunan kemampuan mendengar 
dan memahami pelajaran, kemampuan membaca, kemampuan mengingat, dan kemampuan menalar atau logika [3-5]

Salah satu sumber atau kawasan pembangkit kebisingan yang banyak ditemui adalah jalan raya. Kebisingan di wilayah ini dapat berasal dari suara mesin yang keluar melalui knalpot kendaraan, gesekan antara jalan dan roda, maupun klakson. Kebisingan ini pada level tertentu tidak saja menimbulkan ketidaknyamanan, tetapi dapat mengganggu kesehatan masyarakat yang ada di pinggir jalan raya [6].

Kota Padang merupakan salah satu kota besar yang terletak di Propinsi Sumatera Barat dengan jumlah penduduk lebih dari 1 juta jiwa. Seiring dengan perkembangan pembangunan di Kota Padang menjadikan aktifitas transportasi juga berkembang. Berkembangnya aktifitas transportasi berakibat negatif terhadap kenyamanan di wilayah sekolah yang berada di sekitar jalan raya.

Melalui SK Menteri Negara Lingkungan Hidup Kep.Men No: 48/MEN.LH/11/1996 tanggal 25 November 1996, pemerintah Indonesia telah menetapkan baku tingkat kebisingan untuk berbagai kawasan dan lingkungan kegiatan. Wilayah pemukiman, rumah sakit, rumah ibadah, dan sekolah merupakan wilayah yang sangat sensitif dan mempunyai dampak yang besar terhadap kebisingan. Oleh karena itu telah ditetapkan untuk wilayah tersebut baku tingkat kebisingan wilayah sekolah adalah sebesar $55 \mathrm{~dB}$ (A) [7].

Artikel ini akan membahas hasil pengukuran tingkat kebisingan yang ada di sekolah yang berada di sekitar jalan raya di sepanjang jalan dari Simpang Haru dan Andalas, kota Padang. Pengukuran dilakukan dimulai sejak pagi hari saat sekolah memulai aktifitasnya sampai sore hari dari beberapa titik di wilayah sekolah. Sumber utama kebisingan adalah suara dari jalan raya yang berada di dekat sekolah.

\section{METODOLOGI}

Pengukuran tingkat kebisingan ini dilakukan pada 8 lokasi. Lokasi yang diteliti adalah sekolah yang berada di pinggir jalan raya dari jalan Andalas sampai jalan Simpang Haru. Denah lokasi pengukuran nilai kebisingan di sekolah akibat gangguan suara mesin kendaraan bermotor di jalan raya dapat dilihat pada Gambar 1 .

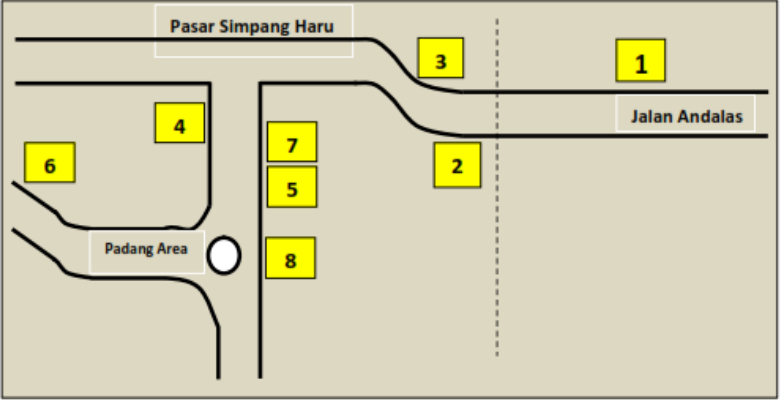

Gambar 1. Denah lokasi sekolah yang ditinjau

Kondisi jalan dan lingkungan di lokasi survei memperoleh data, secara umum hampir sama, karena titik lokasi penelitian berada di jalan utama yang arus lalu lintasnya tercampur. Perbedaannya adalah pada lokasi 1, lokasi 2 dan lokasi 3 terdapat 2 lajur kendaraan sedangkan lokasi 4, lokasi 5, lokasi 6, lokasi 7 dan lokasi 8 berada pada persimpangan 2 lajur dengan jumlah kendaraan yang dilalui lebih banyak di saat jam tertentu.

Dari segi jenjang sekolah kedelapan sekolah tersebut terdiri dari 2 sekolah tingkat dasar (SD), 3 sekolah tingkat menengah pertama (SMP), dan 3 sekolah tingkat menengah atas (SMA/SMK). Sedangkan dari segi pengelolaan, terdiri dari 3 sekolah negeri yang dikelola dinas pendidikan dan 5 sekolah swasta yang dikelola yayasan non pemerintah.

Pengukuran kebisingan di tiap sekolah dilakukan pada empat titik pengukuran berikut:

a. Pinggir jalan raya.

b. Gerbang sekolah.

c. Kelas paling dekat dengan jalan raya.

d. Kelas paling jauh dengan jalan raya.

Adapun jarak keempat titik tersebut berbeda untuk masing-masing sekolah. Jarak gerbang, kelas terdekat dan kelas terjauh dari pinggir jalan 
ditampilkan pada tabel 1. Seluruh sekolah memiliki gerbang di tepi jalan raya.

Tabel 1. Jarak titik pengukuran

\begin{tabular}{|l|l|l|l|}
\hline $\begin{array}{l}\text { No } \\
\text { Sekolah }\end{array}$ & Gerbang & $\begin{array}{l}\text { Kelas } \\
\text { terdekat }\end{array}$ & $\begin{array}{l}\text { Kelas } \\
\text { terjauh }\end{array}$ \\
\hline 1 & $2 \mathrm{~m}$ & $30 \mathrm{~m}$ & $50 \mathrm{~m}$ \\
\hline 2 & $2 \mathrm{~m}$ & $10 \mathrm{~m}$ & $75 \mathrm{~m}$ \\
\hline 3 & $2 \mathrm{~m}$ & $10 \mathrm{~m}$ & $30 \mathrm{~m}$ \\
\hline 4 & $3 \mathrm{~m}$ & $7 \mathrm{~m}$ & $25 \mathrm{~m}$ \\
\hline 5 & $2 \mathrm{~m}$ & $35 \mathrm{~m}$ & $55 \mathrm{~m}$ \\
\hline 6 & $1 \mathrm{~m}$ & $5 \mathrm{~m}$ & $60 \mathrm{~m}$ \\
\hline 7 & $1 \mathrm{~m}$ & $25 \mathrm{~m}$ & $60 \mathrm{~m}$ \\
\hline 8 & $1 \mathrm{~m}$ & $25 \mathrm{~m}$ & $45 \mathrm{~m}$ \\
\hline
\end{tabular}

Selanjutnya pengukuran dilakukan setiap jam mulai dari pukul 07.00 di pagi hari sampai pukul 16.00 WIB di sore hari, dimana dalam satu jam dibutuhkan pengukuran sebanyak empat kali. Satu kali pengukuran dibutuhkan waktu selama 30 detik.

Peralatan yang digunakan adalah Sound Level Meter untuk mengukur tekanan suara dalan $\mathrm{dB}(\mathrm{A})$ dan meteran untuk mengukur posisi pengukuran dari jalan raya.

\section{HASIL DAN DISKUSI}

Dari survei dan pengukuran di lokasi 1 dilakukan pada 4 titik yaitu pinggir jalan (titik 1), gerbang sekolah (titik 2) yang berada di pinggir jalan yang hanya berjarak 2 meter dari jalan, kelas terdekat (titik 3) berjarak 30 meter dari titik 1 dan kelas terjauh (titik 4) berjarak 50 meter dari titik 1 . Hasil pengukuran tingkat tekanan suara dapat diamati pada Gambar 2.

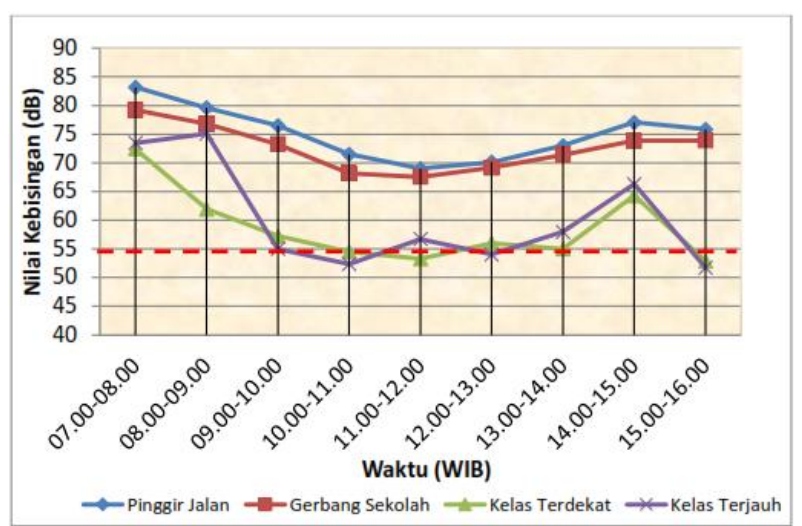

Gambar 2. Hasil pengukuran tekanan suara di sekolah $1(\mathrm{dBA})$

Dari Gambar 2 dapat diketahui bahwa puncak kebisingan rata-rata di sekolah 1 terjadi pada pukul 07.00-08.00 WIB sebesar 83.2 dB dengan kondisi semua siswa masuk kelas di sekolah pada posisi pengukuran di pinggir jalan raya dan volume kendaraan cukup padat. Tingkat tekanan suara mengalami penurunan sampai di siang hari, dan kemudian kembali mengalami kenaikan pada siang menjelang sore dimana aktifitas jalan raya kembali mengalami kenaikan. Pada pukul 15.00-16.00 WIB mencapai $51.8 \mathrm{~dB}$ pada nilai kebisingan rata-rata terendah di kelas terjauh dari jalan raya.

Di lokasi 1 terdapat nilai kebisingan yang berada pada kondisi aman yang telah distandarkan untuk semua kelas baik yang terdekat dan kelas terjauh pada pukul 10.00-11.00 WIB dan pukul 15.0016.00 WIB sebesar $54.5 \mathrm{~dB}$ di kelas terdekat, 52.4 $\mathrm{dB}$ di kelas terjauh dan $52.9 \mathrm{~dB}$ di kelas terdekat, $51.8 \mathrm{~dB}$ di kelas terjauh. Namun di luar jam tersebut tingkat kebisingan berada di atas tingkat kebisingan baku.

Dari segi pola kenaikan dan penurunan tekanan suara, terlihat bahwa pola grafik tingkat tekanan suara terhadap waktu di keempat posisi pengukuran menunjukkan kemiripan, baik di pinggir jalan raya maupun di kelas terjauh dengan level tekanan suara yang berbeda. Ini menjadi indikator bahwa sumber kebisingan utama pada sekolah tersebut berasal dari jalan raya.

Tingkat tekanan suara yang terjadi pada tujuh sekolah lain menunjukkan kecenderungan yang 
serupa seperti yang terlihat pada Gambar 3 sampai dengan Gambar 9.

Gambar 3 memperlihatkan puncak tingkat kebisingan rata-rata di sekolah 2 terjadi pada pukul 07.00-08.00 WIB sebesar 84.8 dB dengan kondisi semua siswa masuk kelas di sekolah pada posisi pengukuran di pinggir jalan raya. Pada pukul 15.00-16.00 WIB mencapai $54.2 \mathrm{~dB}$ pada nilai kebisingan rata-rata terendah di kelas terjauh dari jalan raya.

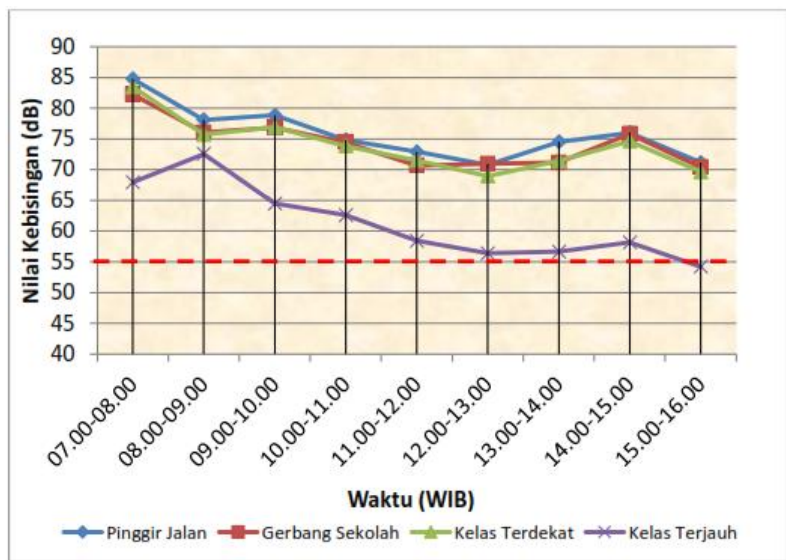

Gambar 3. Hasil pengukuran tekanan suara di sekolah 2 (dBA).

Pada lokasi 2, hampir di semua posisi memiliki tingkat kebisingan di atas ambang baku yang aman, kecuali di kelas terjauh pada pukul 15.0016.00 WIB sebesar $54.2 \mathrm{~dB}$. Nilai tersebut tidak melewati batas minimal yang diizinkan yang terlihat pada garis merah sebesar $55 \mathrm{~dB}$.

Selanjutnya, Gambar 4 menunjukkan puncak tingkat kebisingan rata-rata di sekolah 3 terjadi pada pukul 07.00-08.00 WIB sebesar 86.1 dB dengan kondisi semua siswa masuk kelas pada posisi pengukuran di pinggir jalan raya. Pada pukul 09.00-10.00 WIB mencapai $64.0 \mathrm{~dB}$ pada nilai kebisingan rata-rata terendah di kelas terjauh dari jalan raya. Pada lokasi 3 nilai kebisingan dari hasil pengukuran mulai dari posisi di pinggir jalan raya, gerbang sekolah, kelas terdekat sampai kelas terjauh diperoleh di atas $55 \mathrm{~dB}$. Nilai tersebut melewati batas baku dari tingkat kebisingan yang telah distandarkan.

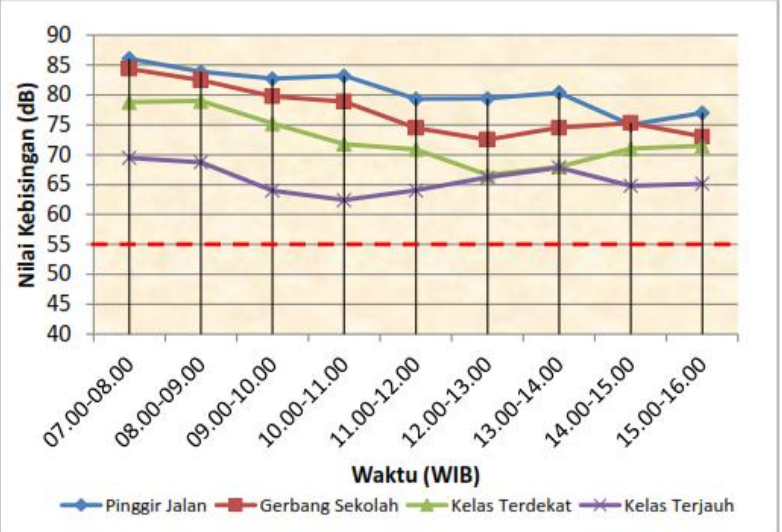

Gambar 4. Hasil pengukuran tekanan suara di sekolah 3 (dBA).

Pola yang hampir seruma terjadi pada sekolah 4 seperti yang diperlihatkan Gambar 5. Pada Gambar 5 terlihat bahwa puncak tingkat kebisingan jalan raya terjadi pada pukul 07.00-08.00 WIB sebesar $89.5 \mathrm{~dB}$ pada kondisi semua siswa masuk kelas. Pada waktu 12.00-13.00 WIB terjadi tingkat nilai kebisingan kendaraan terendah sebesar $64.6 \mathrm{~dB}$ pada kondisi semua siswa dalam ruangan sekolah pada lokasi kelas terjauh dengan jalan raya, dimana nilai tersebut berada di atas batas baku kebisingan.

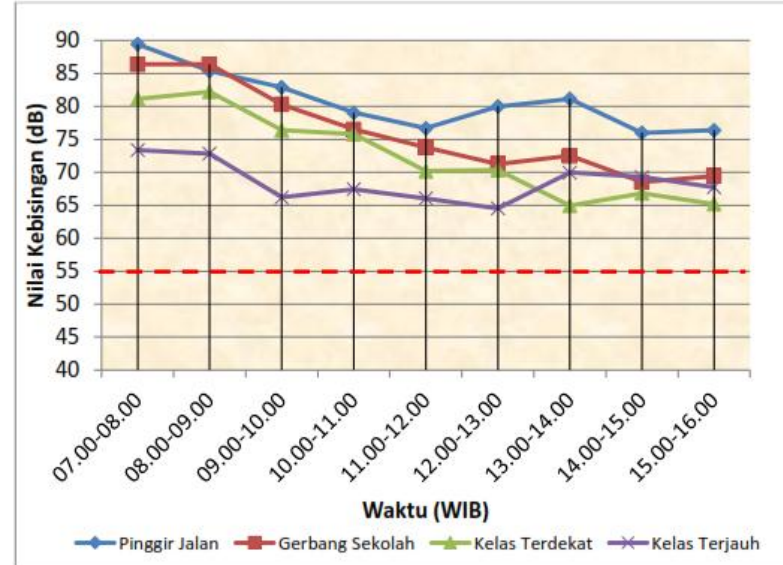

Gambar 5. Hasil pengukuran tekanan suara di sekolah 4 (dBA).

Berdasarkan Gambar 6 diketahui puncak volume kebisingan kendaraan di lokasi 5 pada pukul 07.00-08.00 WIB sebesar $89.8 \mathrm{~dB}$ pada kondisi puncak kepadatan lalu lintas. Pada waktu 11.0012.00 WIB terjadi tingkat nilai kebisingan kendaraan terendah sebesar $58.0 \mathrm{~dB}$ pada kondisi semua siswa dalam ruangan sekolah pada lokasi kelas terjauh dengan jalan raya. Nilai tersebut 
melewati batas baku dari tingkat kebisingan yang diizinkan.

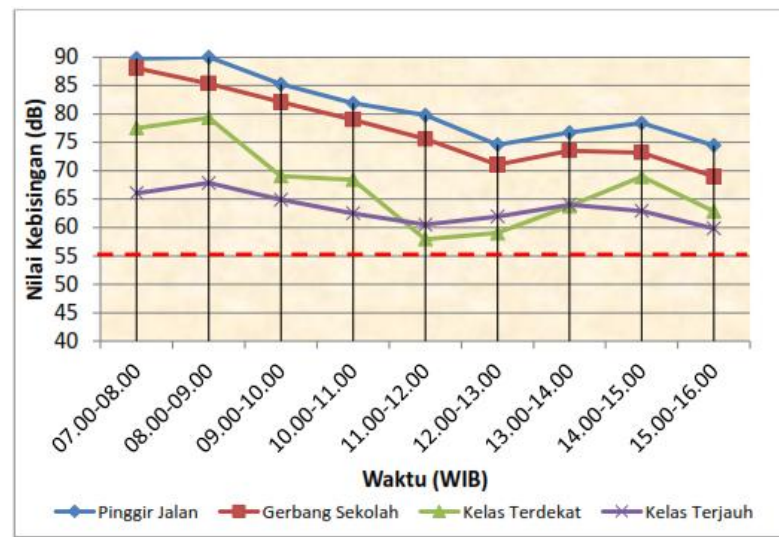

Gambar 6. Hasil pengukuran tekanan suara di sekolah 5 (dBA).

Berdasarkan Gambar 7 diketahui puncak tingkat kebisingan kebisingan di jalan raya di sekolah 6 pada pukul 07.00-08.00 WIB sebesar 84.0 dB pada kondisi semua siswa masuk kelas. Pada waktu 15.00-16.00 WIB terjadi tingkat kebisingan ratarata kendaraan terendah sebesar $48.8 \mathrm{~dB}$ pada kondisi semua siswa sudah pulang dari proses belajar disekolah pada kelas terjauh dengan jalan raya. Pada lokasi ini kelas terjauh mengalami tingkat kebisingan yang paling rendah dan berada pada batas aman.

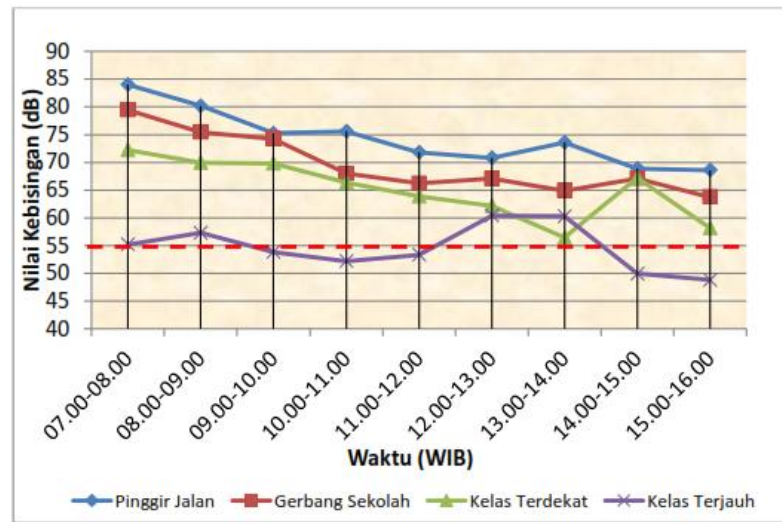

Gambar 7. Hasil pengukuran tekanan suara di sekolah $6(\mathrm{dBA})$.

Berdasarkan Gambar 8 diketahui puncak volume kebisingan rata-rata lokasi 7 terjadi pada pukul 08.00-09.00 WIB sebesar 87.5 dB. Pada pukul 15.00-16.00 WIB mencapai $52.1 \mathrm{~dB}$ pada nilai kebisingan rata-rata terendah di kelas terjauh dari jalan raya.

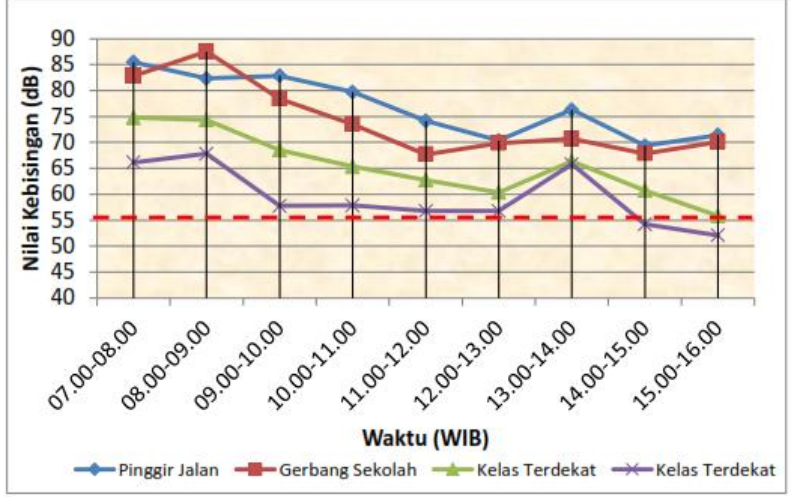

Gambar 8. Hasil pengukuran tekanan suara di sekolah 7 (dBA).

Pada lokasi 8 nilai kebisingan dari hasil pengukuran mulai dari posisi di pinggir jalan raya, gerbang sekolah sampai kelas terdekat diperoleh di atas $55 \mathrm{~dB}$. Sedangkan diposisi pengukuran kelas terjauh diperoleh nilai kebisingan rata-rata sebagian tidak melampaui batas aman atau baku dari tingkat kebisingan yang telah distandarkan yang terlihat pada garis merah Gambar 9 .

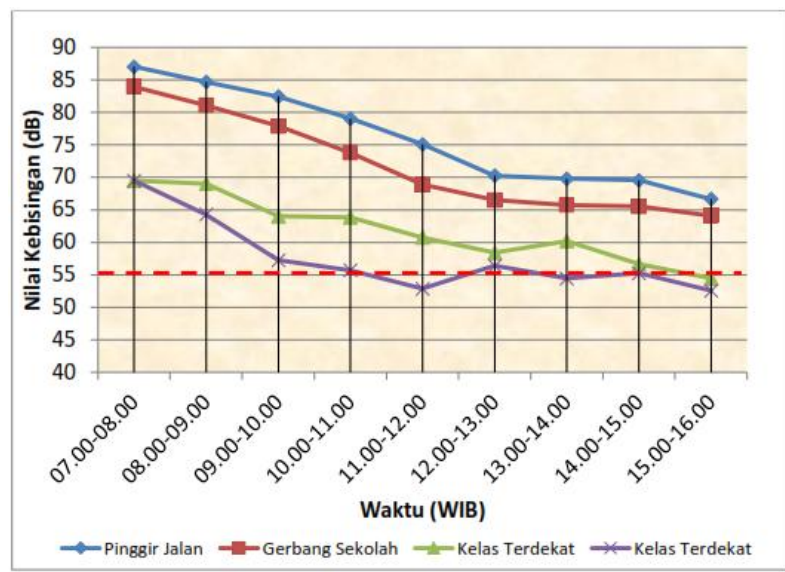

Gambar 9. Hasil pengukuran tekanan suara di sekolah 7 (dBA).

\section{KESIMPULAN}

Berdasarkan hasil pengukuran tingkat nilai kebisingan di sekolah akibat gangguan suara mesin kendaraan bermotor di jalan raya didapatkan gambaran tingkat kebisingan beberapa sekola sebagai berikut:

1. Hampir semua posisi di sekolah yang diamati terpapar oleh tingkat kebisingan yang berada di atas batas baku yang ditetapkan sebesar 55 dBA. Hanya beberapa kelas saja yang berada 
di dalam batas aman dan hanya pada jam-jam tertentu.

2. Nilai kebisingan rata-rata tertinggi diperoleh di posisi pinggir jalan pada pukul 08.00-09.00 WIB di lokasi 5 dengan nilai $90.0 \mathrm{~dB}$ sedangkan nilai kebisingan rata-rata terendah diperoleh di posisi kelas terjauh pada pukul 15.00-16.00 WIB di lokasi 3 dengan nilai $48.8 \mathrm{~dB}$.

Berdasarkan pengukuran tersebut, maka perlu perhatian bagi pihak-pihak yang berkepentingan dalam pengelolaan sekolah yang berada di daerah pinggir jalan tersebut melakukan langkah langkah perbaikan untuk meminimalkan pengaruh kebisingan terhadap kesehatan dan kemampuan belajar siswa.

\section{DAFTAR PUSTAKA}

[1] R.A. Leksono. "Gambaran Kebisingan". Jakarta: FKM. Universitas Indonesia, 2009.
[2] F.N. Setiawan, "Tingkat Kebisingan pada Perumahan di Perkotaan," in Jurnal Teknik Sipil dan Perencanaan, vol. 12, no. 2, 2010, pp. 191-200.

[3] B. M. Shield and J.E. Dockrell. "The effects of noise on children at school: A Review, in $J$. Building Acoustics, vol. 10, No. 2, 2013, pp. 97-106.

[4] K. Karami, M. Cheraghi, M.S. Firoozabadi, "Traffic noise as a serious effect on class teachers in Firoozabad city, Iran," Medical Journal of Islamic World Academy of Sciences, vol. 20, No. 2, 2012, pp 39-42.

[5] A. Kahkashan, V. Shivakumar, "Effects of traffic noise around schools on attention and memory in primary school children," in Internasional Journal of Clinical and Experimental Physiology, vol. 2, No. 3, 2015, pp. 176-179.

[6] S. Djalante, "Analisis Tingkat Kebisingan di Jalan Raya yang Menggunakan Alat Pemberi Isyarat Lalu Lintas (APILL) (Studi Kasus: Simpang Ade Swalayan)," in Jurnal SMARTek, vol. 8, no. 4, pp. 280-300.

[7] NN, "Nilai Ambang Batas Faktor Fisik di Tempat Kerja". KepMenKes Tenaga Kerja, No. 48, 1996, Jakarta. 